\title{
A Comparison of Boerhaave and Haller's Study Guides for Medical Students
}

\author{
TADASHI SAWAI* \\ *Department of History of Medicine, Juntendo University Graduate School of Medicine, Tokyo, Japan
}

\begin{abstract}
Herman Boerhaave and Albrecht von Haller were outstanding figures of medicine in the 18th century and published study guides for medical students. The aim of this study was to clarify the features of these study guides that have not been analyzed, and discuss their historical significance. Literature analysis shows that Boerhaave presented detailed information that was required for medical students, listed the books that students should read for each field of medicine and science, and included mechanics/physics that had not been introduced into medical education before. Subsequently, Haller modified Boerhaave's study guide and increased the amount of bibliographical information. While Boerhaave only referred to a small number of the best books for each topic, Haller referred to comprehensive lists of books. By expanding the bibliographical references, Haller prevented the obsolescence of Boerhaave's study guide and contributed toward sustaining Boerhaave's educational framework. This analysis demonstrates the features of these study guides for medical students in the 18th century.
\end{abstract}

Key words: medical education, history, study guides, bibliography

\section{Introduction}

Herman Boerhaave (1668-1738) and Albrecht von Haller (1708-1777) were two outstanding physicians of the 17-18th century who influenced medicine of that period.

As a medical author and physician, Herman Boerhaave was known for his system of physiology that was based on viewing the human body as a hydraulic system, composed of abundant small vessels. He was also credited for his exhaustive knowledge of chemistry and botany ${ }^{1)}$. He was esteemed for his clinical practice and was often regarded as the founder of clinical education in the hospital at Leiden University. During Boerhaave's 38 years of teaching, the city of Leiden became the center of medical education for students throughout Europe, who brought Boerhaave's teachings back to their homelands. He was praised as the "instructor of all of Europe," and is perceived as a central figure in medicine in the first half of the 18th century ${ }^{2}$.

Albrecht von Haller taught at the University of Göttingen in its early years, after having received his medical education at the University of Tübingen and studied at Leiden University under Boerhaave's instruction. He created the infrastructure for research and education for the faculty of medicine in Göttingen, which would later be recognized as the preeminent university in Germany ${ }^{3)}$. Haller, like Boerhaave, was an active author and physician primarily known for his studies of anatomy, physiology, and embryology. He held a prominent position in the intellectual networks of the time and reviewed many books from various fields in German and French review journals ${ }^{4)}$.

Both Boerhaave and Haller were influential in the leading medical universities of the time and were involved in publishing study guides for medical students in Latin. The Methodus Discendi Artem

\footnotetext{
Tadashi Sawai

Department of History of Medicine, Juntendo University Graduate School of Medicine

2-1-1 Hongo, Bunkyo-ku, Tokyo 113-8421, Japan

TEL: +81-3-3813-3111 E-mail: tsawai@juntendo.ac.jp

〔Received Aug. 19, 2019〕〔Accepted Dec. 6, 2019〕

J-STAGE Advance published date: Feb. 15, 2020
}

Copyright (C) 2020 The Juntendo Medical Society. This is an open access article distributed under the terms of Creative Commons Attribution License (CC BY), which permits unrestricted use, distribution, and reproduction in any medium, provided the original source is properly credited. doi: 10.14789/jmj.2020.66.JMJ19-OA18 
Medicam [Method of Learning Medical Art], hereinafter referred to as the "Methodus Discendi," was published under Boerhaave's name in 1726 and continued to be reprinted. In 1751, Haller published Hermanni Boerhaave Methodus Studii Medici, Emaculata, \& Accesionibus Locupletata ab Alberto ab Haller [Method of the Study of Hermann Boerhaave, Amended and Enriched by Additions from Albrecht von Haller], hereinafter referred to as the "Methodus Studii." The title of Haller's study guide suggested that it was a modified version of the "Methodus Discendi."

Unlike the physicians' works on physiology or clinical medicine, the content and historical status of these study guides have not been thoroughly studied. This paper discusses the contents of these study guides and their significance at the time of publication.

\section{Materials and Methods}

During a preliminary study, the differences between the various editions of both Boerhaave and Haller's study guides were examined. The 1747 edition of "Methodus Discendi" and the 1751 edition of "Methodus Studii" were selected for analysis" ${ }^{5)}$.

There are four major Latin editions of Boerhaave's "Methodus Discendi” and one related English edition, as follows:

A Method of Studying Physick. London, 1719. $8^{\circ}: 331 \mathrm{pp}$.

Methodus Discendi Medicinam. Londini, 1726. $8^{\circ}: 457 \mathrm{pp}$.

Methodus Discendi Artem Medicinam. Londini, 1734. $8^{\circ}: 514$ pp.

Methodus Discendi Artem Medicinam. Londini, 1744. $8^{\circ}: 514 \mathrm{pp}$.

Methodus Discendi Artem Medicinam. Venetiis, 1747. $8^{\circ}: 504 \mathrm{pp}$.

It is well known that these books were not written by Boerhaave himself but were transcribed from his lectures during 1710 by an attendee ${ }^{7)}$. The 1719 English text, A Method of Studying Physick, was possibly based on the same lectures as the Latin edition. However, the present study does not use the English edition, since it differs a great deal from the Latin editions and was not referred to in Haller's "Methodus Studii." A comparison of the four Latin editions revealed that they were fundamentally identical except for the insertion of a few sentences in the 1734 and later versions, reaffirming the suggestion by Daniëls that the 1726 edition was the basis for the subsequent editions ${ }^{8)}$. Therefore, the 1747 edition (the last edition to which Haller could refer to) was chosen for analysis.

For Haller's "Methodus Studii" there are two editions:

Methodus Studii Medici. Amstelodami, 1751. $4^{\circ}$ : two vols. 592 and 577 pp.

Methodus Studii Medici. Venetiis, 1753. 4 : two vols. 688 and $511 \mathrm{pp}$.

The major difference between these two editions was that the 1753 edition modified the text body by reflecting the list of errata as inserted at the end of the second volume of the 1751 edition. However, the 1753 edition contained several new typographical errors that were not found in the 1751 edition, therefore making it unreliable.

This study also used Cornelius Pereboom's 1759 text, the Index Auctorum et Rerum Maximae Memorabilium Methodi Studii Medici Hermanni Boerhaave Emaculatae et Accessionibus Locupletatae ab Alberto ab Haller ${ }^{9}$. This text provided the author and the subject indices for Haller's "Methodus Studii”.

\section{Results}

\section{Composition of Boerhaave's "Methodus Dis- cendi"}

Boerhaave's "Methodus Discendi" was intended to provide a synopsis for the disciplines required for students to become physicians. In the preface, medicine was defined as "the learning which instructs to conserve the present life and health of the human body and to restore the lost ones" (Boerhaave, 1747, p. 22). Based on this definition, the following eight major themes were required for medical students to know: (1) What is the body?; (2) What is the human body?; (3) What kind of a life of a human body is the sound?; (4) What kind of life is the maimed?; (5) What kind of health is the comlete?; (6) What is an injury for sound body?; (7) What kind of aids are special for restoring and repairing life and health; and (8) What method, fixed-dose, opportune time, and adjusted order is to be used for these aids to conserve and recover life and health?

The body of text presented more detailed medical information related to these themes by 
Table-1 The compositions of Boerhaave's “Methodus Discendi” (1747) and Haller's "Methodus Studii” (1751) Boerhaave 1747

\begin{tabular}{|c|c|c|}
\hline Part & Chapter & No. pages \\
\hline Proem & & $5(1.1 \%)$ \\
\hline Pt. 1. Physics in general & Chs. 1-7 & $42(9.2 \%)$ \\
\hline \multirow{2}{*}{ Pt. 2. Physics in general, 2nd part } & Chs. 1-3 & $32(7.0 \%)$ \\
\hline & Chs. 4-6 [motion \& mechanics] & $51(11.1 \%)$ \\
\hline Pt. 3. What physician should learn from physics & Chs. 1-3 & $28(6.1 \%)$ \\
\hline Pt. 4. What physician should learn from chemistry & Chs. $1-2$ & $33(7.2 \%)$ \\
\hline Pt. 3. What physician should learn from botany & Ch. 1 & $26(5.7 \%)$ \\
\hline \multirow{24}{*}{ Pt. 5. What physician should learn from anatomy } & Ch. 1. Anatomical councels & \multirow{8}{*}{$150(32.7 \%)$} \\
\hline & Solid parts & \\
\hline & Ch. 1. Osteology & \\
\hline & Ch. 2. Myology & \\
\hline & Ch. 3. Splanchnology & \\
\hline & Adenography, or description of glands & \\
\hline & Ch. 4. Angiology & \\
\hline & [eye, ear, tongue] & \\
\hline & Ch. 1. Usefulness of parts, or medical theory & $25(5.4 \%)$ \\
\hline & Ch. 2. Pathology & $3(0.7 \%)$ \\
\hline & Ch. 3. Semiotics & $7(1.5 \%)$ \\
\hline & Ch. 4. Hygiene, or dietetics & $4(0.9 \%)$ \\
\hline & Ch. 5. Therapeutics & \multirow{2}{*}{$6(1.3 \%)$} \\
\hline & Ch. 6. Practice & \\
\hline & Ch. 7. Counsels in surgery & \multirow{2}{*}{$13(2.8 \%)$} \\
\hline & Ch. 8. Dietetics & \\
\hline & Ch. 1. Practical study, or counsels for accomplishing & \multirow{7}{*}{$31(6.8 \%)$} \\
\hline & medicine & \\
\hline & Ch. 2. Greek systematic and earliest physicians & \\
\hline & II. Romans & \\
\hline & III. Greek- Gaulish & \\
\hline & Ch. 3. Physicians who wrote about single diseases & \\
\hline & Ch. 4. Physicians who wrote observations & \\
\hline & Ch. 5. Authors who wrote about medical counsels & $3(0.7 \%)$ \\
\hline
\end{tabular}

\begin{tabular}{|c|c|c|}
\hline \multicolumn{3}{|l|}{ Haller 1751} \\
\hline Contents & No. pages & No. authors \\
\hline Proem & $2(0.2 \%)$ & $0(0.0 \%)$ \\
\hline Pt. 1. Physics in general & $17(1.7 \%)$ & $34(0.2 \%)$ \\
\hline Pt. 2. Geometry, or figure and measure of bodies & $12(1.2 \%)$ & $34(0.2 \%)$ \\
\hline Pt. 3. [Mechanics] & $18(1.8 \%)$ & $68(0.4 \%)$ \\
\hline Pt. 4. Physics in special & $83(8.3 \%)$ & $1,743(10.7 \%)$ \\
\hline \multirow{2}{*}{ Pt. 5. Chemistry to honest reader by Haller } & $19(1.9 \%)$ & $224(1.4 \%)$ \\
\hline & $3(0.3 \%)$ & $2(0.1 \%)$ \\
\hline \multirow{2}{*}{ Pt. 6. Botany to honest reader by Haller } & $86(8.6 \%)$ & $1,547(9.5 \%)$ \\
\hline & $3(0.3 \%)$ & $0(0.0 \%)$ \\
\hline
\end{tabular}




\begin{tabular}{|c|c|c|}
\hline Pt. 7. Counsels of anatomy & \multirow{8}{*}{$320(31.9 \%)$} & \multirow{8}{*}{$5,274(35.0 \%)$} \\
\hline Sect. 1. Solid parts & & \\
\hline Sect. 2. Bones of human body & & \\
\hline Sect. 3. Muscles of human body & & \\
\hline Sect. 4. Viscera of human body & & \\
\hline Sect. 5. Adenography & & \\
\hline Sect. 6. Angiology & & \\
\hline Sect. 7. [eye, ear, tongue] & & \\
\hline Pt. 8. Usefulness of parts, or medical theory & $9(0.9 \%)$ & $0(0.0 \%)$ \\
\hline Pt. 9. Pathology & $96(9.6 \%)$ & $1,880(11.5 \%)$ \\
\hline Pt. 10. Semiotics & $17(1.7 \%)$ & $384(2.4 \%)$ \\
\hline Pt. 11. Hygiene or dietetics & $23(2.3 \%)$ & $538(3.3 \%)$ \\
\hline Pt. 12. Therapeutics & $5(0.5 \%)$ & $25(0.2 \%)$ \\
\hline Pt. 13. Counsels for surgery & $99(9.9 \%)$ & $1,355(8.3 \%)$ \\
\hline Pt. 14. Practical study, or counsels for accomplishing medicine & \multirow{6}{*}{$145(14.4 \%)$} & \multirow{6}{*}{$1,941(11.9 \%)$} \\
\hline I. Greek systematic physicians & & \\
\hline II. Roman systematic practitioners & & \\
\hline III. Greek- Gaulish & & \\
\hline Physicians who wrote about single diseases & & \\
\hline Physicians who wrote observations & & \\
\hline Pt. 15. History of medicine & \multirow{2}{*}{$47(4.7 \%)$} & \multirow{2}{*}{$806(4.9 \%)$} \\
\hline Authors who wrote about direction of medical study & & \\
\hline & total 1,004 & total 16,305 \\
\hline
\end{tabular}

The numbers in parentheses are the percentages of the total number of pages or the total number of authors.

dividing the book into several parts that corresponded to the study subjects including the physical body, mathematics (geometry), mechanics, chemistry, botany (pharmacology), the human body, diseases (anatomy and theoretical medicine), and therapies (practical medicine). For each subject, its features and relationship to medicine or other medical subjects were established and the leading authors in that field were mentioned. An overview of the required knowledge in each field was included, and a summary of previously established findings were briefly presented.

The upper part of Table- 1 summarizes the composition of Boerhaave's "Methodus Discendi" (1747). Each part is subdivided into sections and chapters; however, the subdivisions were inconsistent, and the chapter numbers were not in order. Furthermore, some bridging sentences were inserted before the beginning of a new part or section. These sentences summarized the previous description and previewed the subject that would be shown in the next part or section. Such inserted sentences reflected that the "Methodus Discendi" was based on a transcription from Boerhaave's oral lectures.

\section{Bibliographical information of study guides in} "Methodus Discendi"

The last division of "Methodus Discendi" was the Auctores, Qui de Consiliis Medicis Scripserunt [Authors Who Wrote About Medical Counsels], and introduced the books that were written to guide medical students.

In the opening sentence, the policy for citing authors was described as follows: "Many authors of medicine themselves shared the same business as I, which was spread through their medical writings intending to guide the medical study" (Boerhaave, 1747, p. 451).

Subsequently, five books and their authors were mentioned. Three of the five provided advice on medical learning (one is a book that included work by five authors), and the other two were bibliographies of medical books. The former was published by "the authors, who wrote about both instructions and books," and the latter as "giving the whole 
view of all authors" (Boerhaave, 1747, p. 451). The purpose of both types of books as well as "Methodus Discendi” was helping the students find the right books.

\section{Structure of Haller's "Methodus Discendi”}

Haller modified Boerhaave's "Methodus Dis- cendi" to make it more useful for readers while keeping the general framework intact.

Haller's most substantial modification was the voluminous additions of bibliographical information in the footnotes. As shown in the downer part of Table-1, Haller republished Boerhaave's text with few alterations to the original text, and kept the

\section{DE A N ATO O I N

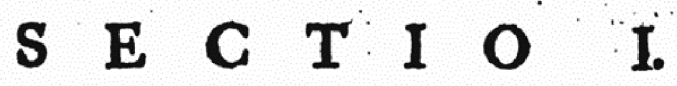 \\ De folidis partibus.}

$\mathbf{H}$

E partes funt corpufcula exigu, fatis inter fe fimilia, fimplicifima, terre, Itria, ex fluidis humoribus adveatis ad finguta loca fecreta, \& adpofita cullo atis partibus, \& hace funt prima elementa, ex quibus hoc nottrum corpus fit. $\mathrm{Si}$ rogetur, guxenzm fint uttrma farmina minimaruma partium noftrarum; dicemus corpora efle exigua, \& hoc clare demonftratur apud anatomicos, nam maxima pars corporis fit ex vafis, vafa fiumt ex membranis, quxe imvolute faciunt cavum; he etiam membrana funt iterum ex vafis, qua vada membeanam confiruentia ite rum conftant membranis, heec iterum ex vafis; donec ad ultimum vas perveniamus quod habet membranam, non ex vafis jam amplios (alirer enim non effec ultimum vas), (fid ex fibris compofitam, que ergo fibre, ultimam membranam conftituentes, non fiunt cavx, aliter effent vafa, fed mern filamenta folida (a)...He vero. fo, bra (b) conftant ex meris partibus folidis minimis, exiguis, \&c. Ultima ergo par-

(a) Non neceffe eft furf bic repetere quxe alibi dixi de membranarum compofitione. Ex cerx neque omnes, neque fola vafi, habent, ex quibos componantur. In Arachnoidea membrana; adeo magna, quar poft duram Membraoem longifiema fit in corpore humano, vala nulla demonAraca lunt. Deinde membrame verx, qux vafa habent, pinguntur \& percurnuntur vafis, non conAtant. Maceratio vero, anelogia cum membranis per morbos natis, fimilitudo cum laminis cellutiofis, demonftrant membranas ex brevibus filis cellulofis fieri, in fe invicem ftipatis, atque fe comprehendentibus, five nunc preterea vafa ad membranas conttituendas accedant fivc fecus. Vide noftros commentarios in Inf. Boorb. n. CCCCXXXIX. CCCI. \&c. \& Davibis CHristoPHOR I ScBobingeri Difl. de tele cellalofe digntitate. Gotting. 1748. 4. \& video nubc ex Cli. RogaAR Diff. at mutritione eandem mentem effe B. S. AlbtNo.

(b). Fibram veteribus fatis neglectam \& finb ipfa fimpliciare fua lanentem FR ANcrscus GL isson rUs primus contemplatus eft, \& de fibra ejufque nawira animali irritabiti in L. de Ventrioulb of inteftinis dixit.

Deinde LAURENTIUs BsLLIN Us L. de contraftione naturali proxter vim irritabilem, per experimenta cognitam, etiam hypothefin de fibre fabrica mechanica pro ea vi explicanda propofuir. Eum virum plerique recentiorum imitati funt.

JoH A N NES QUINCY in III. E/fay, qui prodlit cum commentario in tranfpirationem Sanctorii, fere fequitur BELLINUM.

De fibris earumque intervallis \& ex neivis origine etiam conjecturam adfort GuIL I rL mus Cots.

J. Domin. San ToR INus in Opere de fructure, ev motw fitra $\&$ in Tractatu de nutritione, Venet. 1705. 8. Fibram omnem habuit pro vafe netveo minimo, \& ejus fabricam fere Belliniano more contemplatus eft.

GEORGIUS BAGLIVUs in L. de fibra motrice do morbofa, Rom, 1702. Ultrajecti 1703. 8. edito, fibras membranxe durx \& nufcutorum inprimis confiderat.

Hermannus Boerhave de fibra mere terred, cum glutine aqueo \& oleoro, ejufque compofitione in vafa \& $x$ membranas \& rigefcentia fucceffiva, theoriam novam \& in hoc noftro opere propofuir, \& in aphorifmis. Eum $\mathrm{Cl}$. a SwIE TEN \& plurimi recentiorum fecuti funt.

Grorerus CHEYNB de fibre matwe ejufque laxe morbis. Londin. 1725. 8.

CL. Wusss de dj/crimine motus elaftici of viralis fibrarums. Altdorf. 1735. Diff.

Jor. de GorT R in Exercitatione de motw vitali. Amftelodam. 1737. 4 ftamen five fibram primigeniam defcribit, ejufque vim contractilem diftractioni mufculofe oppofitam, unde omnis in corpore hunano alterna motuum feries \& perpetuitas in motu oriatur.

Higronymus David Gaubius in Difr. Inaug. de föidis corporis bumami partibus, Leidx

1725 . 
order of topics but added footnotes to the bottom of each page.

The number of footnotes was vast and often occupied the majority of a page (as shown in Figure-1), or even the entire page itself. Of the total 1,004 pages, 504 consisted solely of footnotes by Haller, and 860 included footnotes covering more than half of the page. Due to this increase in pages and the enlargement of the format, the amount of information was estimated to be more than six times the original. The "Methodus Studii" had approximately double the number of pages as the "Methodus Discendi" the former with 1,004 pages and the latter with 459 . On the other hand, the "Methodus Discendi" contained around three times as many characters per page as the latter.

Haller's footnotes primarily consisted of bibliographical information. Boerhaave's "Methodus Discendi" listed the names of the leading authors when discussing each topic within the text; however, the title or year of publication was not adequately provided. Haller provided sufficient bibliographical information in his footnotes to allow the readers to refer to the books.

Haller also added numerous bibliographical details for works that the "Methodus Discendi" did not mention. Haller (1751) explained the reason for inserting this additional bibliographical information was because approximately 40 years after Boerhaave's original lecture (which was transcribed and published as "Methodus Discendi"), many books had been published, and Haller did not want to ignore them. Besides the books that he himself read, he presented information on related books for which only bibliographical information was available from either bibliographical catalogs, or another author's description. Such books were marked with asterisks.

The rightmost column the downer part of Table-1 represents the number of authors that Haller mentioned in the footnotes as counted from the author index to Haller's "Methodus Studii," published by Pereboom ${ }^{9}$.

A total of 16,305 authors are mentioned in the footnotes, and this number is around 60 times as many as the number of authors listed in the author index of Boerhaave's “Methodus Discendi." With the exception of part eight that dealt with physiology, Haller's bibliographical information referenced more authors. Haller explained that the reason he did not provide any additional information concerning authors in part eight was because physiology was closely related to anatomy and chemistry, and that the authors writing about physiology were listed in the anatomy and chemistry parts.

To assess Haller's additions, this author made a comparison of the number of pages in "Methodus Discendi" and "Methodus Studii." As shown in Table-1, both books devoted the most pages to anatomy. Boerhaave's "Methodus Discendi" assigned a considerable number of pages to natural philosophy (physics, mathematics, chemistry, botany) before the anatomy section, while Haller's "Methodus Studii" has more pages regarding medical content than natural philosophy. A similar trend was seen in the number of authors listed in the footnotes added by Haller.

In addition to the expansion of the bibliographical information in the footnotes, the readability of the books was improved by rearranging the chapter numbers of "Methodus Discendi" and eliminating bridging sentences inserted before the beginning of a new part or section.

\section{Bibliographical information in Haller's "Meth- odus Studii”}

The pages that concerned the history of medicine were significantly increased by the insertion of bibliographical information.

While "Methodus Discendi" dealt with the bibliographies of medical books and methods of medical learning, Haller also added biographies of physicians, dictionaries, and books on the history of medicine and current medicine.

Haller listed 1,162 books in the footnotes of this division. Table- 2 summarizes the classification of these books according to their subject, and the number in parentheses represents the number of books that Haller did not read by himself but marked with an asterisk in his footnotes. The classification was determined by the author of this study based on the title and contents of each book. As shown in Table-2, the more recent the period, the more books that were referred to, and this tendency was displayed for the books of every subject.

Although bibliography for medical books was 
Table-2 Number of books cited by Haller in Pt. 15

\begin{tabular}{lccccccc}
\hline Year & Bibliography & Biography & Dictionary & History & Medicine & Method & Subtotal \\
\hline-1500 & $2(0)$ & $9(1)$ & $3(1)$ & $10(0)$ & $15(0)$ & $4(1)$ & $43(3)$ \\
$1500-1600$ & $12(5)$ & $35(20)$ & $5(2)$ & $10(5)$ & $72(52)$ & $19(7)$ & $153(91)$ \\
$1601-1700$ & $30(9)$ & $98(35)$ & $7(2)$ & $82(20)$ & $159(63)$ & $46(11)$ & $422(140)$ \\
$1701-1751$ & $48(2)$ & $117(5)$ & $7(2)$ & $111(7)$ & $222(37)$ & $39(4)$ & $544(57)$ \\
total & $92(16)$ & $259(61)$ & $22(7)$ & $213(32)$ & $468(152)$ & $108(23)$ & $1,162(291)$ \\
\hline
\end{tabular}

The numbers in parentheses are the sum of the books which Haller marked with asterisk to show that he did not read

small, Haller included detailed comments on each and evaluated the accuracy, abundance of information, and the usefulness for readers. Approximately twenty-five percent of the books were unread by Haller and marked with asterisks. Of course, newer books were more likely to be read by Haller than older ones. However, he assigned asterisks to more books that were published before the year 1500 than to those published in the 16th century. The reason for this was because many books published before 1500 were written by ancient Greek and Roman authors, and had been reprinted several times. However, books written in the 16th and 17th centuries were rarely resold, and the percentage of those unread by Haller increased.

\section{Discussion}

There have been studies on Boerhaave and Haller from a variety of perspectives, but little attention has been given to their study guides for medical students. When these study guides were mentioned, no particular consideration was given to their contents.

For example, Lindeboom's definitive study of Boerhaave's bibliography treated the "Methodus Discendi" as one of Boerhaave's works, and dealt with Haller's "Methodus Studii" as a revision of the "Methodus Discendi," as both were based on a lecture by Boerhaave ${ }^{7)}$. Lindeboom mentioned van der Hoeven's analysis and translated his assessment that "Haller totally misjudged the intention of the work" into English ${ }^{10)}$. However, van der Hoeven did not closely scrutinize and compare both study guides, and did not explain why he believed Haller had made a misjudgment. Thus, previous studies have dealt with both the "Methodus Discendi" and "Methodus Studii" together, have followed the evaluation by van der Hoeven, and did not make a comparison between the guides.
Similar to Haller's studies, the "Methodus Studii" has not been discussed in detail or compared with "Methodus Discendi." Even in the research on Haller's biography and in the works by Steinke and Holenstein, there were few references to "Methodus Studii ${ }^{11)}{ }^{12)}$." However, a comprehensive analysis by Catherine of the intellectual network surrounding Haller contained references to the "Methodus Studii, ${ }^{4}$ " although her analysis referred to it purely in relation to the network, and did not focus on its origin or its contents. Moreover, the "Methodus Studii" was sometimes referred to as a record of the use and dissemination of books by researchers other than Haller in the 18th century. However, these references utilized the bibliographical information in the "Methodus Studii" for historical study and no consideration was given to Haller's book itself.

Furthermore, the existence of other study guides from the same period have been ignored in previous studies. There were many study guides by other authors which were reviewed in the last divisions of Boerhaave's and Haller's guides (aside from those on medical and scientific knowledge).

Based on the above results, this discussion investigates the historical significance of the study guides of Boerhaave and Haller by giving attention to the subjects that were suggested for medical students to learn, and as bibliographies of reference books.

\section{Study guides as instructions for medical students}

The learning subjects listed by Boerhaave (Table-1) corresponded to the teaching subjects at Leiden University of Medicine during Boerhaave's time. As revealed by Sakai, in the curriculum of the Leiden University five subjects - theoretical medicine, practical medicine, anatomy/surgery, botany, 
and chemistry - were taught at the beginning of the 18th century, and there was a corresponding professorship to each subject ${ }^{13)}$. As written in "Methodus Discendi," the connection to botany, anatomy/surgery, and chemistry was apparent, but the other subjects also had a less apparent connection.

Theoretical medicine dealt with physiology, pathology, semeiotics, hygiene, and therapeutics. Boerhaave himself wrote a textbook on theoretical medicine entitled Institutiones Medicae that covered these subjects ${ }^{14)}$. In "Methodus Discendi," the chapter discussing the function of body was titled De Usu Partium sive Theoria Medica [Usefulness of Parts or Medical Theory], and the following chapters dealt with pathology, semeiotics, hygiene, and therapeutics, meaning that these five parts corresponded to theoretical medicine. In addition, these parts contained references to the writings of Fernel and Sennert, both of whom had published a textbook of theoretical medicine before Boerhaave ${ }^{14)}$.

The remaining chapters of "Methodus Discendi" concerned practices, surgery, and dietetics, and correspond to the contents of a practical medicine textbook ${ }^{15}$. However, while practical medicine textbooks of the early modern times comprehensively described specific therapies for various diseases, the description of the relevant chapters in "Methodus Discendi" was limited to explaining that practical medicine was characterized by specific diagnoses and therapies. It defined surgery as a therapy that uses hands, and dietetics as a therapy that was aimed at improvement through lifestyle and food intake, and described what these two fields were.

In regard to the subjects of mechanics and physics, Boerhaave appeared to teach these subjects between 1705 and 1717 at Leyden before Willem Jacob 's Gravesande become the professor of philosophy, and medical students might have attended these lectures ${ }^{1)}{ }^{16}$. The use of mechanics in medicine was of great interest to Boerhaave, who delivered the oration De Usu Ratiocinii Mechanici in Medicina [The Use of Mechanistic Reasoning in Medicine] in $1703^{1)}$. Therefore, Boerhaave's intention to introduce physics/mechanics into medical education was reflected in his "Methodus Discendi."
The study subjects listed in "Methodus Discendi" were different from those in the study guides before Boerhaave. A significant difference between this text and the earlier study guides was that Boerhaave made mechanics and physics essential for medical students. Of the seven study guides of the other authors mentioned by Boerhaave in "Methodus Discendi" (Boerhaave listed three books, and Hermannus Conringius' In Universam Artem Medicam Sigunlas Ejus Partes Introductio compiled four other study guides), among these five described recommended subjects for medical students and did not mention mechanics and physics. Caspar Bartholin's De Studio Medico (1625) mentioned classical languages, rhetoric/ logic, metaphysics, physics/mathematics, medical material, botany, natural history, anatomy, dietetics, therapeutics, surgery, pharmacology, and medicaments. Petrus Castellus' Optimus Medicus (1637) listed classical languages, logic, mathematics, anatomy, surgery, theoretical medicine, and practical medicine. Joannis Antonides van der Linden's Manuductio Ad Medicinam (1639) required that theoretical medicine, practical medicine, and chemistry be studied. Hermannus Conringius' In Universam Artem Medicam ... (1687) mentioned physiology, pathology, semiotics, therapeutics, medicaments, medical material, botany, pharmacology, surgery, and dietetics. Günther Christoph Schelhammer's Via Regia Ad Artem Medendi (1700) recommended botany, anatomy, physiology, medical material, pathology, and therapeutics.

In the study guides published after "Methodus Discendi," similar subjects were recommended. In the footnotes of "Methodus Studii," Haller provided bibliographical information of 18 study guides that appeared after 1726, which was the year that "Methodus Discendi" was first published. Among these 18 study guides, three described essential subjects for medical students. Of these three, Armstrong and Detailing's study subjects were the traditional ones. In Armstrong's An Essay For Abridging The Study Of Physick (1735) he recommended anatomy, chemistry, dietetics, pathology, surgery, and pharmacology; while Detailing's Quaestio (1734) recommended anatomy, chemistry, dietetics, pathology, surgery, and pharmacology.

However, Heister's Compendium Institutionum Sive Fundamentorum Medicinae (1736) mentioned 
subjects similar to those in "Methodus Discendi": Latin, logic, physics/mechanics, mathematics, anatomy, botany, physiology, pathology, semiotics, dietetics, therapeutic, medical material, chemistry, pharmacology, and surgery.

Heister's study guide was constantly reprinted alongside "Methodus Discendi," which indicated that the study subjects written in the medical study guides during the first half of the 18th century had shifted to incorporate physics and mechanics.

In light of the historical role that the "Methodus Discendi" played in changing the recommended learning subjects, the significance of Haller's "Methodus Studii" was to inherit and strengthen Boerhaave's framework of medical learning, and to prolong its obsolescence. As shown in Table-1, the "Methodus Studii" inherited the chapter structure of "Methodus Discendi," which means that it inherited the framework of its study subjects from Boerhaave. Furthermore, by modifying the chapter structure and improving the readability, the contents of "Methodus Studii" could be more easily understood, and by adding information in the footnotes that concerned books from ancient times to the period that it was written in, the quantity and quality of bibliographical information was strengthened. In particular, the information about books published in each study subject since the "Methodus Discendi" made it possible to learn about each subject by referring to the latest literature within Boerhaave's framework, thereby preventing its obsolescence.

This evaluation of the significance of Haller is supported by the references to "Methodus Studii" in the medical study guides published afterward. For example, the Encyclopédie Méthodique: Médecine (1821) used "Methodus Studii Medici" as a general title for books on medical learning, and dealt with Haller's "Methodus Studii" as representative of the genre, yet it did not refer to Boerhaave's "Methodus Discendi."

\section{Study guides as medical bibliographies}

Boerhaave was known to have frequently recommended books for students to read, as evidenced by the episode that the price of the books discussed in favorable terms by Boerhaave had doubled ${ }^{16)}$.

Boerhaave listed two medical bibliographies similar to "Methodus Discendi." The "Methodus
Studii” inherited this characteristic as a bibliography of recommended books. Thus, a large amount of the footnotes in Haller's “Methodus Studii” did not contain new information, but rather an extension of "Methodus Discendi." Haller wrote that "A doctor must know all the authors, the good ones to learn from them, the mediocre ones to draw from them something good, even the bad ones so as not to lose in reading his time which one must be stinging with ${ }^{17)}$," and unlike Boerhaave who only listed the best books, Haller comprehensively listed books by many authors including mediocre publications.

As a result, "Methodus Studii" included accurate and voluminous bibliographical information for each subject. Later, Haller planned and published bibliographical catalogs for botany, anatomy, surgery, and practical medicine; of which the first three were published by himself and the last was posthumously published after being edited and amended on the basis of Haller's manuscripts ${ }^{18)}$.

Hence, "Methodus Studii" was later evaluated as one of the bibliographical catalogs, and Thomas Young's Introduction To Medical Literature (1813) cited "Methodus Studii" as the most important book in which useful bibliographical information for medical students was written.

\section{Conclusion}

In early modern times, many study guides for medical students were written with the intention of helping medical students to study and select appropriate books. Boerhaave's "Methodus Discendi" provided the basic framework for teaching subjects within the medical education system of the 18th century. Notably, the introduction of mechanics and physics into medical education was a significant feature in Boerhaave's study guide. Haller's "Methodus Studii" inherited the framework of Boerhaave's study guide, and by enriching the bibliographical information, Haller served to prevent Boerhaave's obsolescence and sustain his framework.

This study drew these conclusions for both Boerhaave and Haller's study guides by comparison with study guides by other authors, thus indicating the usefulness of historical analysis. There are many other author's study guides from the early modern period that remain unexamined. Even a detailed analysis and comparison of the contents of 
Boerhaave and Haller's study guides has not yet been fully completed. Further investigations should be conducted to examine the numerous study guides in more detail and should take into account the influence of both Boerhaave and Haller.

\section{Acknowledgments}

This work was supported by JSPS KAKENHI, Grant Number JP 18K00265. The author wishes to thank Professor Emerita Shizu Sakai at the Department of History of Medicine, Juntendo University Graduate School of Medicine for constant encouragement.

\section{References}

1) Lindeboom GA: Boerhaave and His Time. Leiden: E.J. Brill, 1970.

2) Knoeff R: Chapter 11: Hermann Boerhaave at Leiden: Communis Europae praeceptor. In: Grell OP, Cunningham A, Arriabalaga, J, eds. Centres of Medical Excellence? Medical Travel and Excellence in Europe, 15001789. Farnham: Ashgate, 2010: 269-286.

3) Steinke H: Chapter 12: Science, practice, and reputation: The University of Göttingen and its medical faculty in the eighteenth century. In: Grell OP, Cunningham A, Arriabalaga, J, eds. Centres of Medical Excellence? Medical Travel and Excellence in Europe, 1500-1789. Farnham: Ashgate, 2010: 287-304.

4) Catherine F: La pratique et les réseaux savants d'Albrecht von Haller (1708-1777), vecteurs du transfert culturel entre les espaces français et germaniques au XVIIIe siècle. Paris: Honoré Champion, 2012.

5) Boerhaave H: Hermanni Boerhaave, phil. et med. doctoris; Methodus discendi artem medicam, in duas partes divisa. Venetiis: apud Thomam Bettinelli, 1747.

6) Haller A: Hermanni Boerhaave viri summi, suique praeceptoris methodus studii medici emaculata \& accessionibus locupletata ab Alberto ab Haller. 2 vols. Amstelaedami: Jacobi a Wetstein, 1751.
7) Lindeboom GA: Bibliographia Boerhaaviana. List of Publications Written or Provided by H. Boerhaave or Based upon his Works and Teaching. Leiden: E.J. Brill, 1950.

8) Daniëls C: Verslag van den hoofdbestuurder-bibliothecaris aan de commissie tot het nazien der bibliotheek, over het tijdvak van 1 Mei 1910-1 Mei 1911. Nederlands Tijdschrift voor Geneeskunde, 1911; 55: 2123-2132.

9) Cornelius P: Index auctorum et rerum maximae memorabilium methodi studii medici Hermanni Boerhaave emaculatae et accessionibus locupletatae ab Albreto ab Haller. Lugduni Batavorum: Jacobi. a Wetstein, 1759.

10) van der Hoeven C, Van der Post C: Akademieleven. Amsterdam: Utrecht, 1866; 167.

11) In: Steinke H, Boschung U, Proß W, eds. Albrecht von Haller: Leben - Werk - Epoche. Göttingen: Wallstein Verlag, 2009.

12) In: Holenstein A, Steinke H, Stuber M, eds. Scholars in Action. Leiden: Brill, 2013.

13) Sakai T: History of Medical education in Europe (1): Education in the Western traditional medicine before the 18th century. History of medical education: old and new, East and West. Hosei University Press, 2019; 5-54. (in Japanese)

14) Sakai T, Tadashi S: Boerhaave (1668-1738) and His "Institutiones medicae". Journal of the Japanese Society for the History of Medicine (NIHON ISHIGAKU ZASSHI), 2012; 58: 357-372. (in Japanese)

15) Sakai T: The Books of Practica medicinae and their Authors in Europe before the End of 18th Century. Journal of the Japanese Society for the History of Medicine (NIHON ISHIGAKU ZASSHI), 2015; 61: 273297. (in Japanese)

16) van Berkel K, Van Helden A, Palm LC: The History of Science in the Netherlands: Survey, Themes and Reference. Leiden: Brill, 1999.

17) [Anon]: Hermanni Boerhaave, viri summi suique praeceptoris, methodus studii medici. Bibliotheque raisonné des ouvrages des savans de L'Europe, 1751: 47: 121-134.

18) Krämer F: Albrecht von Haller as an 'Enlightened' Reader-Observer. In: Cevolini A, eds. Forgetting Machines: Knowledge Management Evolution in Early Modern Europe. Brill, 2016; 224-242. 